LAW RENCE LIVERMORE N A T IO N A L LABORATORY

Facility Safety Plan CMLS-410r1 Change Memo

G.A. Cooper

February 7, 2007 
This document was prepared as an account of work sponsored by an agency of the United States Government. Neither the United States Government nor the University of California nor any of their employees, makes any warranty, express or implied, or assumes any legal liability or responsibility for the accuracy, completeness, or usefulness of any information, apparatus, product, or process disclosed, or represents that its use would not infringe privately owned rights. Reference herein to any specific commercial product, process, or service by trade name, trademark, manufacturer, or otherwise, does not necessarily constitute or imply its endorsement, recommendation, or favoring by the United States Government or the University of California. The views and opinions of authors expressed herein do not necessarily state or reflect those of the United States Government or the University of California, and shall not be used for advertising or product endorsement purposes.

This work was performed under the auspices of the U.S. Department of Energy by University of California, Lawrence Livermore National Laboratory under Contract W-7405-Eng-48. 


\section{Facility Safety Plan CMS Complexes

\author{
$\mathrm{X}$ Major Change $\square$ Minor Change
}

Date: September 12, 2006

TO: Distribution

FROM: Hazards Control, ES\&H Team 2

SUBJECT: $\quad$ Facility Safety Plan CMS Complexes - Major Change

This Change Memo serves to revise Facility Safety Plan CMS Complexes, effective September 30, 2006 as follows:

1. Section 1.2, B151 Complex entire paragraph has been revised as follows:

The B151 Complex includes B151, B152, and B154. Each of these facilities is considered a separate facility for the purposes of hazard classification and chemical/radiological inventory. B151 and 154 provide office, laboratory, and electronics shop facilities for laboratory operations in a broad range of chemical, biological, and radiochemical research. B152 is a cement block structure located on the west side of B151 that provides storage.

2. Section 3.1.1, Chemical Inventory Tracking and Control, $3^{\text {rd }}$ paragraph has been revised as follows:

NOTE: The Tier 2 Safety Basis Document for the B151 Complex administratively separates the three facilities in the B151 Complex (B151, B152, and B154) to allow each facility to maintain separate and independent chemical inventories/limits.

3. Section 3.2, Safety Basis Envelope, Facility Hazard Classification and Principal Controls, $1^{\text {st }}$ and $2^{\text {nd }}$ paragraph are revised as follows:

Document 3.1, "Nonnuclear Safety Basis Program" of the ESEH Manual specifies the methodology used to determine the inventory limits and controls for chemical, radiological, and explosive inventories for B132N, B151 Complex, and B235. The older Document 3.1, "Safety Analysis Program" of the ES\&H Manual specifies the methodology used for B241. Implementation of these controls is coordinated through the ADFM. An IWS is required for new or changed operations not commonly performed by the public (i.e. WAL [Work Authorization Level] B and greater).

The safety basis envelope for the CMS Complex facility operations is defined by Hazard Analysis Reports (HAR) and Tier 2 and Tier 3 Safety Basis Documents (see Table 3-1). The SBD for the B151 Complex administratively segments that Complex in terms of radiological and chemical inventory allowing each facility (B151, B152, and B154) to maintain separate and individual chemical and radiological inventories. 
4. Section 3.2, Table 3-1: Safety Basis Summary for CMS Complexes, 2 nd row has been revised as follows:

\begin{tabular}{|l|l|l|}
\hline Facility & Safety Basis Document & Hazard Classification \\
\hline $\begin{array}{l}\text { 151, 152, } \\
\text { and 154 }\end{array}$ & $\begin{array}{l}\text { Tier 2 Safety Basis Document for the B151 Complex (B151, } \\
\text { B152, and B154), Rev 0, July 13, 2006 }\end{array}$ & Low Hazard \\
\hline
\end{tabular}

5. Section 3.2.1.1, Key Safety Limits, Table 3-2: Key Chemical Limits Summary for CMS Complexes, has been revised as follows:

\begin{tabular}{|c|c|c|c|}
\hline Facility & $\begin{array}{l}\text { Chemical } \\
\text { Name }\end{array}$ & $\begin{array}{l}\text { Safety Basis Limit } \\
\qquad(\mathrm{lbs} / \mathrm{kg})\end{array}$ & $\begin{array}{c}\text { FSP (administrative) Limit } \\
\text { (lbs/kgs) }\end{array}$ \\
\hline $132 \mathrm{~N}$ & All & $\begin{array}{l}\text { Lesser of Q-List } \\
\text { values Q1(100 } \\
\text { meters) or Q0 ( } 200 \\
\text { meters) }\end{array}$ & $75 \%$ of Safety Basis Limit \\
\hline 151 & $\begin{array}{l}\text { Chlorine } \\
\text { trifluoride gas }\end{array}$ & $15 \mathrm{lbs} / 6.8 \mathrm{~kg}$ & $11.25 \mathrm{lbs} / 5.1 \mathrm{~kg}$ \\
\hline 151 & $\begin{array}{l}\text { Sulfur Dioxide } \\
\text { gas }\end{array}$ & $\begin{array}{l}11.4 \mathrm{lbs} / 5.2 \mathrm{~kg} \\
\text { Restricting Flow } \\
\text { Orifice less than } \\
0.031^{\prime \prime} \text { is required } \\
\text { for cylinders with } \\
\text { concentrations } \\
\text { greater than } 10 \% \text { by } \\
\text { weight. }\end{array}$ & $8.55 \mathrm{lbs} / 3.9 \mathrm{~kg}$ \\
\hline 151 & $\begin{array}{l}\text { All other } \\
\text { chemicals }\end{array}$ & $\begin{array}{l}\text { Lesser of Q-List } \\
\text { values Q1(100 } \\
\text { meters) or Q0 ( } 300 \\
\text { meters) }\end{array}$ & $75 \%$ of Safety Basis Limit \\
\hline 151 & $\begin{array}{l}\text { Liquid } \\
\text { Nitrogen }\end{array}$ & $39,600 \mathrm{lbs} / 18,000 \mathrm{~kg}$ & $29,700 \mathrm{lbs} / 13,500 \mathrm{~kg}$ \\
\hline 152 & All & $\begin{array}{l}\text { Lesser of Q-List } \\
\text { values Q1(100 } \\
\text { meters) or Q0 (300 } \\
\text { meters) }\end{array}$ & $75 \%$ of Safety Basis Limit \\
\hline 154 & All & $\begin{array}{l}\text { Lesser of Q-List } \\
\text { values Q1(100 } \\
\text { meters) or Q0 ( } 300 \\
\text { meters) }\end{array}$ & $75 \%$ of Safety Basis Limit \\
\hline
\end{tabular}




\begin{tabular}{|c|c|c|c|}
\hline Facility & $\begin{array}{c}\text { Chemical } \\
\text { Name }\end{array}$ & $\begin{array}{l}\text { Safety Basis Limit } \\
(\mathrm{lbs} / \mathrm{kg})\end{array}$ & $\begin{array}{l}\text { FSP (administrative) Limit } \\
\text { (lbs/kgs) }\end{array}$ \\
\hline 235 & All & $\begin{array}{l}\text { Lesser of Q-List } \\
\text { values Q1(100 } \\
\text { meters) or Q0 }(600 \\
\text { meters) }\end{array}$ & $\begin{array}{l}75 \% \text { of Safety Basis Limit for the } \\
\text { total facility inventory and less } \\
\text { than } 1 \text { pound of Be Powder for } \\
\text { the entire facility. }\end{array}$ \\
\hline 241 & Mercury & $563 \mathrm{lbs} / 256 \mathrm{~kg}$ & $282 \mathrm{lbs} / 128 \mathrm{~kg}$ \\
\hline 241 & $\begin{array}{l}\text { All other } \\
\text { chemicals }\end{array}$ & $\begin{array}{l}29 \text { CFR } 1910.119 \text { TQ } \\
\text { or } 40 \text { CFR } 355 \text { TPQ } \\
\text { whichever is less }\end{array}$ & $75 \%$ of Safety Basis Limit \\
\hline
\end{tabular}

6. Section 3.2.1.2, Key Explosive Limits, Table 3-3: Key Explosive Limits Summary for CMS Complexes, has been revised as follows:

\begin{tabular}{|c|c|c|c|}
\hline Facility / Room & $\begin{array}{l}\text { UNO Hazard } \\
\text { Class/Division }\end{array}$ & $\begin{array}{c}\text { Quantity Allowed in } \\
\text { Operations a }\end{array}$ & $\underset{a, b}{\text { Total Quantity Allowed }}$ \\
\hline $132 \mathrm{~N} / 1901$ & 1.1 and 1.5 & $\begin{array}{l}\text { Less than or equal to } \\
10 \text { grams }\end{array}$ & 1000 grams \\
\hline $132 N / 1903$ & 1.1 and 1.5 & $\begin{array}{l}\text { Up to } 10 \text { grams low- } \\
\text { risk contact } \\
\text { operations }\end{array}$ & 10 grams \\
\hline $132 N / 2695$ & 1.1 and 1.5 & $\begin{array}{l}\text { Sum of all operations } \\
\text { less than or equal to } 5 \\
\text { grams. }\end{array}$ & 50 grams \\
\hline $132 \mathrm{~N} /$ other labs & 1.1 and 1.5 & $\begin{array}{l}\text { Less than or equal to } \\
1 \text { gram }\end{array}$ & $\begin{array}{c}\text { Less than or equal to } 1 \\
\text { gram }\end{array}$ \\
\hline $151 /$ any lab & 1.1 and 1.5 & $\begin{array}{l}\text { Each operation } \\
\text { limited to less than to } \\
10 \text { mg of non- } \\
\text { primary explosives } \\
\text { and less than } 1 \mathrm{mg} \text { of } \\
\text { primary explosives. } \\
\text { Multiple operations } \\
\text { allowed per room. }\end{array}$ & $\begin{array}{l}\text { Less than or equal to } 1 \\
\text { gram }\end{array}$ \\
\hline $152 /$ any lab & 1.1 and 1.5 & $\begin{array}{l}\text { Each operation } \\
\text { limited to less than } 10 \\
\text { mg of non-primary } \\
\text { explosives and less } \\
\text { than } 1 \mathrm{mg} \text { of primary } \\
\text { explosives. Multiple } \\
\text { operations allowed } \\
\text { per room. }\end{array}$ & $\begin{array}{l}\text { Less than or equal to } 1 \\
\text { gram }\end{array}$ \\
\hline
\end{tabular}




\begin{tabular}{|c|l|l|c|}
\hline Facility / Room & \multicolumn{1}{|c|}{$\begin{array}{c}\text { UNO Hazard } \\
\text { Class/Division }\end{array}$} & $\begin{array}{c}\text { Quantity Allowed in } \\
\text { Operations }\end{array}$ & $\begin{array}{c}\text { Total Quantity Allowed } \\
\mathrm{a}, \mathrm{b}\end{array}$ \\
\hline $154 /$ any lab & 1.1 and 1.5 & $\begin{array}{l}\text { No explosives work } \\
\text { is allowed. }\end{array}$ & None \\
\hline $235 /$ any lab & 1.1 and 1.5 & $\begin{array}{l}\text { Sum of all operations } \\
\text { limited to less than or } \\
\text { equal to 1 gram. }\end{array}$ & $\begin{array}{r}\text { Less than or equal to } 1 \\
\text { gram }\end{array}$ \\
\hline $241 /$ any lab & 1.1 and 1.5 & $\begin{array}{l}\text { Less than or equal to } \\
10 \mathrm{mg}\end{array}$ & $\begin{array}{r}\text { Less than or equal to } 10 \\
\text { mg }\end{array}$ \\
\hline
\end{tabular}

7. Section 3.2.1.4, Key Biological Limits, $2^{\text {nd }}$ paragraph has been added as follows:

Select Agents (as defined in Document 13.6 of the LLNL ESEH Manual) are not permitted in B151, B152, or B154. The only biological operation allowed in B152 is the storage of biowaste.

8. Section 3.3, Table 3-4. Building Safety Features BSF, has been updated as follows:

\begin{tabular}{|l|l|c|}
\hline Facility & Description & Institutional \\
\hline All (except B152) & Fire detection and alarm & $X$ \\
\hline All (except B152) & Fire suppression & $X$ \\
\hline B132N & $\begin{array}{l}\text { B132N separation of the utilities infrastructure and } \\
\text { the two-hour (minimum) fire-rated separation } \\
\text { between the CMS and DNT areas }\end{array}$ & \\
\hline B132N & $\begin{array}{l}\text { Non-propagating explosive storage arrays } \\
\text { High Vacuum Fluorination System reaction vessel } \\
\text { manifold }\end{array}$ & \\
\hline B151 &
\end{tabular}

9. Section 3.4.1.4, Egress/Fire Safety/Housekeeping, $1^{\text {st }}$ paragraph has been revised as follows:

All means of egress, as defined in Document 22.5, "Fire" and 11.2, "Hazards --General and Miscellaneous" of the ESEH Manual, (aisle ways, exit ways, corridors, stairs, etc.) shall be kept clear of storage, obstructions, and debris. Fire doors (between building segments and in stairwells) shall be properly labeled and never propped open. General housekeeping practices shall be applied to ensure fire safety and to maintain clear egress routes. In the event of a power outage, personnel may become trapped in the building elevators. In a power outage, remain calm. An emergency light will come on in the elevator, and the bell alarm system can be activated to summon help. The battery power should last about one hour.

10. Section 4.2.2, B132N Non-propagating explosives storage arrays and 4.2.3, B151 High Vacuum Fluorination System reaction vessel manifold have been added as follows:

\subsubsection{B132N Non-propagating explosives storage arrays}


Non-propagating storage arrays for explosive materials have been identified as BSF for $\mathrm{B} 132 \mathrm{~N}$ in order to prevent the accidental detonation of one sample from causing a detonation of other samples. Acquisition of non-propagating arrays must be approved in advance by the ADFM and an Explosives Safety Engineer. There are no maintenance or testing requirements for non-propagating arrays.

\subsubsection{B151 High Vacuum Fluorination System reaction vessel manifold}

The High Vacuum Fluorination System (HVFS) reaction vessel shall be maintained in a configuration consistent with the specifications in Engincering Safety Note LLSN04-503AA, Reaction Vessel for High Vacuum Fluorination System. Proposed changes to the Engineering Safety Note shall be reviewed and approved according to the requirements of the Engineering Design Safety Standards, Chapter D: ME, EE, and Eng. Dir. Safety Notes.

11. Section 6.1, Introduction, $3^{\text {rd }}$ paragraph has been added as follows:

The FPOC is responsible for maintaining the Self Help Shed in their area.

12. Section 6.1.1, Credible Emergencies, $1^{\text {st }}$ sentence has been revised as follows:

The CMS Complex Hazard Analysis Reports (HAR) and Tier 1 and Tier 2 SBDs identify B132N, B151, B152, B154, B235 an B 241 as Low Hazard, Radiological Facilities.

13. Section 7.0 , References, $7.13,7.14,7.15,7.16$ and 7.17 have been changed as follows:

7.13 B241 Hazard Analysis Report, January 2001

7.14 Tier 2 Safety Basis Document for B132N, July 28,2006, UCRL-AR-223227

7.15 Tier 2 Safety Basis Document for B235, July 28, 2006, UCRL-AR-223230

7.16 Tier 2 Safety Basis Document for B151 Complex (B151, B152, and B154), July 13, 2006

7.17 Engineering Design Safety Standards, Chapter D: ME, EE, and Eng. Dir. Safety Notes

14. Appendix C Radiological Operations, Section 2.4, "Administrative Control Levels", 3rd paragraph has been added as follows:

Radioactive material may be excluded from the administrative inventory summation of equation C-3 at the discretion of the ADFM and only if it meets the exclusion eligibility criteria specified in attachment 1 of DOE-STD-1027-92. These criteria include:

a. Material is contained within a sealed source capsule engineered to meet the special form testing specified by the Department of Transportation (DOT) in 49 CFR 173.469 or testing specified by ANSI N43.6 "Sealed Radioactive Source Categorization,"

Sealed sources lacking documentation that the source or prototypes of the source have been tested and have passed the tests specified by DOT or ANSI are ineligible for exclusion and are included in the facility administrative radiological inventory summation, or

b. Material is stored within a DOT Type B shipping container with current certificates of compliance and the materials stored are authorized by the certificate. 
Materials contained in DOT Type B shipping containers lacking current Certificates of Compliance are ineligible for exclusion and are included in the facility administrative radiological inventory summation.

c. Certified sealed sources excluded from the facility inventory comply with the LLNL sealed source control policy (ESEH Manual, Document 20.2). This includes periodic inventories and leak checks.

Sources failing periodic leak checks are no longer eligible for exclusion. They are removed from service and included in the facility administrative radiological inventory summation of equation C-3. Radioactive materials that have been excluded from the administrative inventory ARE NOT excluded from the operational inventory summation of equation C-1. 